\title{
TEMPORAL AND SPATIAL PATTERNS ON SERRA, SCOMBEROMORUS BRASILIENSIS (TELEOSTEI, SCOMBRIDAE), CATCHES FROM THE FISHERIES ON THE MARANHÃO COAST, BRAZIL
}

\author{
BATISTA, V. da S. ${ }^{1}$ and FABRÉ, N. N. ${ }^{2}$ \\ ${ }^{1}$ Laboratório de Avaliação e Manejo da Pesca, Departamento de Ciências Pesqueiras, Faculdade de Ciências \\ Agrárias, Universidade do Amazonas, CEP 69077-000, Manaus, AM, Brazil \\ ${ }^{2}$ Laboratório de Ecologia, Departamento de Biologia, Instituto de Ciências Biológicas, Universidade do Amazonas, \\ CEP 69077-000, Manaus, AM, Brazil \\ Correspondence to: Vandick da Silva Batista, Laboratório de Avaliação e Manejo da Pesca, Departamento de \\ Ciências Pesqueiras, Faculdade de Ciências Agrárias, Universidade do Amazonas, CEP 69077-000, \\ Manaus, AM, Brazil, e-mail: vbatista@fua.br \\ Received March 14, 2000 - Accepted April 25, 2000 - Distributed November 30, 2001
}

(With 3 figures)

\begin{abstract}
The displacement pattern of the serra, Scomberomorus brasiliensis, in North-eastern Brazil was analyzed from landing data recorded from the fleet fishing serra. Serra fishery has two seasons: from September to February (demersal species plus serra), and from March to August (almost only large amounts of serra). S. brasiliensis relative abundance increases similarly along the coast from March, but decreases first on the West coast from June. Records indicate that serra is near the coast at least until September/October in Eastern grounds. From October to March (strongest spawning season) there is no record of shoals on the coast. We concluded that the Maranhão coast is just a part of the migration circuit of $S$. brasiliensis that may exceed 300 nautical miles.
\end{abstract}

Key words: fishery, displacement, serra, Maranhão.

\section{RESUMO}

Padrões espaciais e temporais na captura da serra, Scomberomorus brasiliensis (Teleostei, Scombridae), na pesca efetuada na costa do Maranhão, Brasil

O padrão de deslocamento da serra, S. brasiliensis, no Nordeste do Brasil foi analisado a partir de dados registrados pela frota pesqueira direcionada a sua captura. Há duas estações principais de pesca: de setembro a fevereiro (pesca das espécies demersais e serra) e de março a agosto (praticamente apenas grandes capturas de serra). A abundância de S. brasiliensis aumenta semelhantemente ao longo da costa desde março, mas ocorreu diminuições na costa Ocidental desde junho. Registros indicam que a serra está mais perto da costa, pelo menos até setembro/outubro, nos pesqueiros da costa norteoriental. De outubro a março (estação de desova mais intensa), não há registro de cardumes na costa. A partir dos padrões observados na pesca maranhense e nas informações da literatura, concluímos que a costa do Maranhão é apenas uma parte do circuito de migração de $S$. brasiliensis nas águas do Nordeste do Brasil, sendo que o circuito total deve ser superior a 300 milhas náuticas.

Palavras-chave: pesca, deslocamentos, serra, Maranhão. 


\section{INTRODUCTION}

Scomberomorus brasiliensis is distributed along the Caribbean and Atlantic coasts of Central and South America between the limits of $20^{\circ} \mathrm{N}$ and $30^{\circ} \mathrm{S}$ (Collette \& Russo, 1984). It is an important fishery resource of the western Central Atlantic waters (Stevenson, 1981) and of Northeastern Brazil (Fonteles-Filho, 1988). It has been harvested with gill nets and also with trolling lines and fishing-weirs in Brazil (Fonteles-Filho, 1988) and with beach seines in Trinidad (Sturm, 1978).

There is no register of extensive migrations for S. brasiliensis (Collette \& Russo, 1984), however its fishery is typically seasonal in Colombia (Dahl, 1971), Venezuela (Griffiths \& Simpson, 1972), Trinidad (Sturm, 1978), and the State of Ceará in Northeastern Brazil (Fonteles-Filho, 1988). The authors of these papers analyzed local patterns of occurrence for the species for a year, however no one evaluated spatial and temporal patterns of the catches throughout their range although this should be done since it has serious economic consequences for done serra fishery.

Maranhão is on the Northeast coast of Brazil. There is a large artisanal fishery which harvests $S$. brasiliensis (vernacular name: serra) and other species such as Macrodon ancylodon and Cynoscion acoupa (Sciaenidae) with drift gill nets (ODA, 1988). Although the shore line is about $640 \mathrm{~km}$ long, the serra fishing fleet is based only on São Luís Island due to logistical constraints. This fleet has different kinds of fishing boats (Fabré \& Batista, 1992) which spend much traveling to the fishing grounds (about 15\%-20\% of each trip).

We intend to determine the distribution and displacement pattern of serra in Maranhão throughout the year as well as the spatial and temporal distribution of the fishery effort. Both objectives could optimize the performance of the artisanal fishery and would provide insight into its migratory circuit strength.

We designed our hypothesis based on information gathered from the fishermen in Maranhão. They believe that migrant shoals come from the northwest in April, bordering the coast until July when $S$. brasiliensis spreads from Pericau (Long.: $44^{\circ} 20^{\prime} \mathrm{W}$ ) to the west. At the end of the rainy season the serra goes back to its origin. We elaborated our hypothesis based on this information, evaluated it using catch-effort data from the fishery on the Maranhão coast, and then compared it with literature information.

\section{MATERIAL AND METHODS}

Catch data from the serra fishing fleet were collected from July 1987 to March 1989 at the main fish landing center of Maranhão State, the fishing community of Raposa (Lat.: $2^{\circ} 24^{\prime}$ 'S L Long.: $\left.44^{\circ} 04^{\prime} \mathrm{W}\right)$.

From a fleet of 53 serreira fishing boats, 10 were selected proportionally to the sizes of each boat strata. They recorded the following data: number of days fishing, number of sets, duration of sets (in hours), fishing grounds, and catch of serra and by-catch species in $\mathrm{kg}$. Three boat strata were considered, according to Fabré \& Batista (1992) classification. Fleet type 1 has open-decked canoes with Curicaca sailing rigs; type 2 has flushdecked canoes with Curicaca sailing rigs and motor power of less than $45 \mathrm{HP}$; and type 3 has motor power of at least $45 \mathrm{HP}$.

The time fishing (in hours) times the net length (in $\mathrm{km}$ ) was the effort measure used, following Fabré \& Batista (1996) recommendations.

The study area was split into seven sub-regions clustering fishing grounds (Fig. 1) according to coastal morphology, oceanographic characteristics (Sudepe, 1976), and descriptions of the fishermen.

Estimates of CPUE values were transformed $[y=\ln (x+1)]$ to reduce the effects of contagion (Elliott, 1971) and the means computed for each site cluster. Homocedasticity was tested with Barttlet's test $(\mathrm{a}=0.05)$. Analysis of variance (ANOVA) was then performed among fishing grounds for each month. If ANOVA was significant at the 0.05 level, Fisher's LSD multiple range test was performed to determine which fishing grounds were different from one another at the same level (Steel \& Torrie, 1985).

\section{RESULTS}

The highest relative abundances were found from April 1988 to June 1988 along the coast (Fig. 2). 


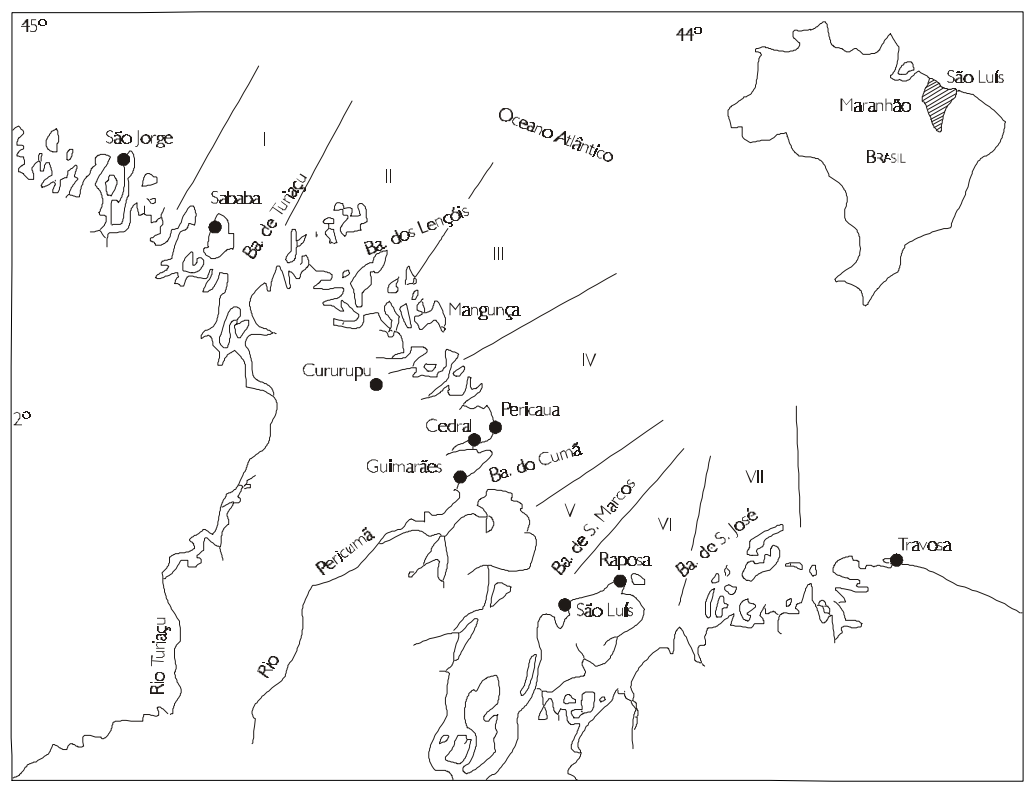

Fig. 1 - Map of the coast of Maranhão. Roman numbers indicate sub-regions divided by heavy solid lines.

Other high values were obtained in October 1987 in sub-region II, in November 1987 in subregion IV, and in October and December 1987 in sub-region I but these values were exceptions in relation to the general pattern observed for these months and were not repeated the following year.

The CPUE mean of July 88-February 89 was less than the mean of July 87-February $88\left(\mathrm{t}_{243: 0.05}=\right.$ 4.3839), reaching the extreme of null catches from November 88 to February 89 in the sub-regions around Raposa.

The farthest region of Sababa (SR I) showed the highest sub-region abundances in July, August, September, and December 1987, and in January, February, and July 1988. Only in October and November 1987 was the abundance recorded not the highest. In spite of this, there was no more fishing there from August 1988 unlike the same period in 1987 when this fishing ground had been common.

Smaller relative abundances in 1988 were found at both the beginning and end of the year in the months of January, February, November, and December. In March two times more serra was recorded than in February and from March to April it doubled again, reaching a maximum value in May with $4.14 \mathrm{~kg} / \mathrm{m} * \mathrm{fh}$. This increment in the relative abundance of the resource on the coast was homogeneous along the coast in March $\left(\mathrm{F}_{3,20}=0.071\right.$; $\mathrm{p}>0.05)$, April $\left(\mathrm{F}_{1.14}=2.467 ; \mathrm{p}>0.05\right)$, and May $\left(\mathrm{F}_{2,25}=3.349 ; \mathrm{p}>0.05\right)$.
In June, the abundance of serra differed among sub-regions (Table 1). The eastern subregions of Canal do Navio and Raposa showed greater abundances than the western ones, resulting in different groups (Fig. 3).

The relative abundance in June is lesser than that found in May in sub-regions II and III but was still at the same level as on the east coast.

The decrease in serra abundances was continuous throughout July, August, and September without marked differences between sub-regions. The abundance only increased in March 1989, when the values were again at least two times greater than those found in February.

\section{DISCUSSION}

Scombrids typically migrate long distances for feeding and reproduction purposes (Moyle \& Cech Jr., 1982; Collette \& Russo, 1984). S. brasiliensis abundances along the North coast of South America have been described as seasonal. In Trinidadian waters, Whiteleather \& Brown (1945, apud Sturm, 1978) observed high abundances from May to July (wet season) and Sturm (1978) extended this period to September according to unpublished data.

In the State of Ceará (Northeast Brazil), scombrid abundance is greater from October to March (transition from wet to dry season) (Fonteles-Filho, 1968; Costa \& Paiva, 1969). 


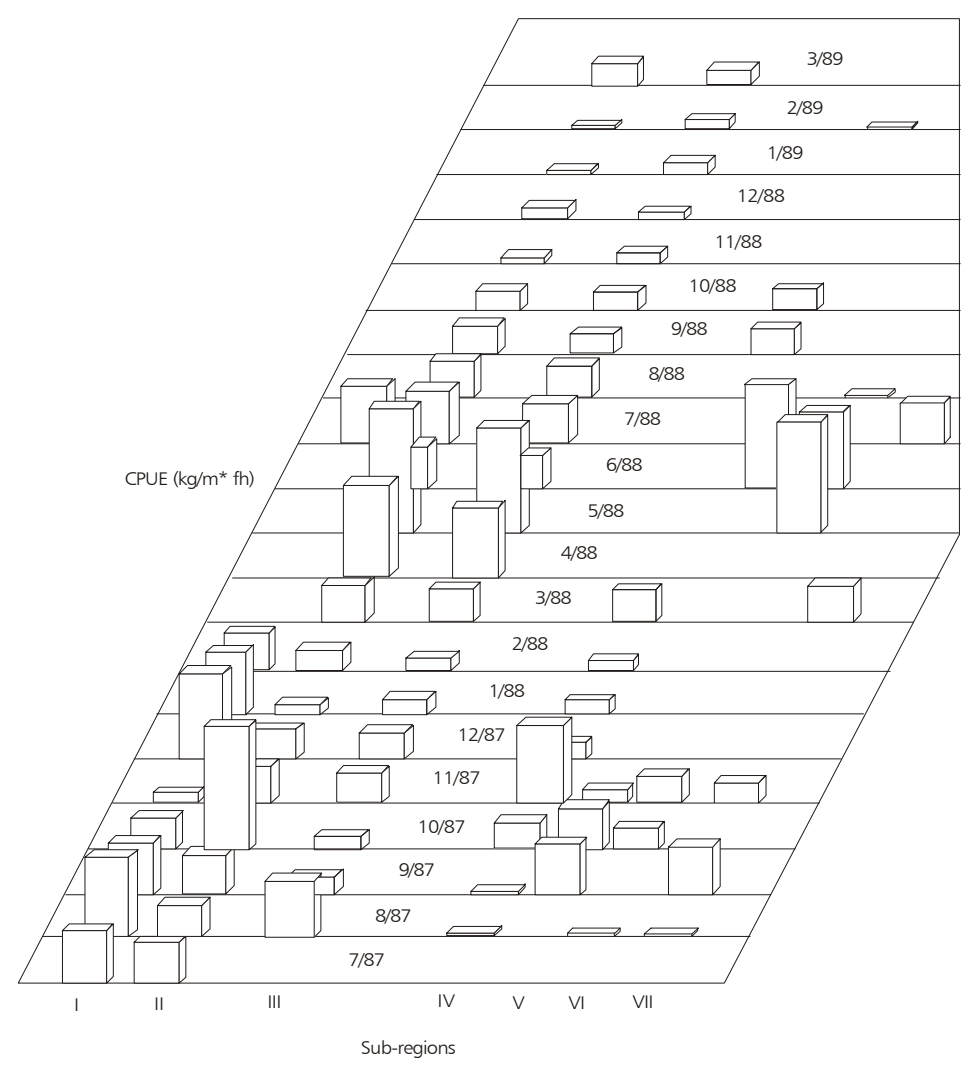

Fig. 2 - Variation of the CPUE computed as a function of the serra fishery effort.

The Maranhão coastal waters were surveyed in July and August 1974 by a Brazilian governmental agency (Sudene, 1976). Their results indicated that catches decreased to about $30 \%$ from July to August. This evidence was associated with fishermen's information which suggested a period of abundance from May to August. ODA (1988) also observed that catches are highest between May-August and suggested that their size is associated with years of high rainfall.

The serra fishery in Maranhão can be separated into two periods during the year. The first is from September to February, when serra are the main target of the fishery together with a few demersal species, specially Cynoscion microlepidotus, Micropogonias furnieri, sharks, and catfishes (Batista \& Fabré, MS). In this period, the effort did not diminish in any strata in spite of rougher weather conditions than are usual during the March-September period. These results disagree with local descriptions of reduced effort at this time because strong winds make maneuvering extremely difficult for small boats.
Our hypothesis that the migrants come from the Northwest was not accepted. Migrating serra began to be vulnerable to the fishery as of March but its abundance on the coast increased similarly in all sub-regions up to May, when the fleet is totally dedicated to serra fishery.

Relative abundance began to decrease in June in the Western coastal waters but continued to be high in the Eastern grounds suggesting movement of the migrants to the East at this time. The abundance continued to decrease in July and August but without any other particular directional trend. This displacement pattern caused us to reject the hypothesis of an immediate return to the west from these waters.

Sturm (1978) suggested a circular migratory pattern for S. brasiliensis from Trinidad due to reproductive or feeding requirements. The reproduction season of serra is during the dry weather months, ranging from October to April in the Gulf of Paria, Venezuela (Sturm, 1978) and from September to March in Ceará, Brazil (Gesteira \& Mesquita, 1976). 
TABLE 1

ANOVA table for CPUE means at different sub-regions in June (SS - sum of squares; MS - mean square).

\begin{tabular}{|l|c|c|c|c|}
\hline \multicolumn{1}{|c|}{ Source of variation } & SS & df & MS & F-ratio \\
\hline Between sub-regions & 28.4730 & 4 & 7.1183 & $24.596^{*}$ \\
\hline Within sub-regions & 8.6821 & 30 & 0.2894 & \\
\hline
\end{tabular}

* Significant $(\mathrm{p}<0.05)$.

\begin{tabular}{|c|c|c|}
\hline Sub-region & Homogeneous groups \\
\hline IV & \\
III & \\
II & & \\
VI & \\
V & \\
\hline
\end{tabular}

Fig. 3 - LSD contrast test for log-transformed CPUE means at different sub-regions on June.

However, the scarcity of ripe running or spent females in the catches from both regions (Gesteira, 1972; Menezes, 1976; Sturm, 1978) indicate that spawn occurred outside these grounds, probably in deeper waters as was already observed for other Scombrids of the Western Atlantic Ocean (Gorbunova \& Salabarria, 1968).

The inshore feeding season coincides with the period of greater abundance of $S$. brasiliensis in Trinidadian waters (May-September) (Sturm, 1978). However, the opposite occurs in Ceará (Menezes, 1970) where more food was found in stomachs collected from June to September, although the species feeds year-round, suggesting that the stock feeds the on coast when it is not offshore.

The abundance of serra from March to August in Maranhão waters might be due to the feeding habits of the species since almost all fishes eviscerated in the markets at this period had food remains in the stomachs and few ripe gonads were observed. These migrants came to the area following clupeoid shoals which enter the estuaries of the region from July to August (Sudam, 1983; Sudam/UFMa, 1985; Batista \& Rêgo, 1996) becoming inaccessible to serra predation.

The serra shoal leaves the area to the east, in the direction of Ceará waters, around July/ August. Serra reaches peak abundance in Ceará around September-October and gradually decreases during the following months. The shoal is not near the coast when it returns to the west since fishermen have neither captured nor observed serra coming from the west coast and it has not been frequently observed by fishermen in western states of Northeast Brazil. Gesteira \& Mesquita (1976) recorded that the most intensive spawning season for the species was found to be in October-March. At that time the large shoals of migrant serra had left the coast of Maranhão and Ceará.

The migration of $S$. brasiliensis into Trinidadian waters occurs along a smaller distance (about 70 nautical miles) than likely occurs in Brazilian waters (at least 300 nautical miles) but in both cases reproduction grounds were not confirmed, suggesting that the circuits may be greater and farther from coast than is known.

Acknowledgments — We thank the Financiadora de Estudos e Projetos (Brazil) and the Overseas Development Administration (United Kingdom) for financial support. We also thank Richard K. Stride for his assistance and for supplying the data; Natalino Soares, Jose Camurin, Paulo R. Patricio for their support to our activities and to Dr. Ning. L. Chao and Dr. Miguel Petrere $\mathrm{Jr}$. for the revision of the first draft.

\section{REFERENCES}

BATISTA, V. S. \& RÊGO, F. N., 1996, Análise de associações de peixes, em igarapés do estuário do Rio Tibiri, Maranhão. Rev. Brasil. Biol., 56(1): 163-176. 
BATISTA, V. S. \& FABRÉ, N. N., Manuscript in analysis, A pesca artesanal efetuada no litoral maranhense, pela frota operando com a rede de emalhar serreira a partir da comunidade do Raposa, MA.

COLLETTE, B. B. \& RUSSO, J. L., 1984, Morphology, systematics, and biology of the Spanish mackerels (Scomberomorus maculatus, Scombridae). Fish. Bull., Seattle, 82(4): 545-692.

COSTA, R. S. \& PAIVA, M. P., 1969, Notas sobre a pesca da cavala e da serra no Ceará - dados de 1968. Archos. Cien. Mar., 9: 89-95.

DAHL, G., 1971, Los peces del norte de Colombia. Inderena Publ., Bogotá, Colombia, 391p.

ELLIOTT, J. M., 1971, Some methods for the statistical analysis of samples of benthic invertebrates. Freshwater Biol. Assoc. Sci. Publ., 25: 144.

FABRÉ, N. N. \& BATISTA, V. S., 1992, Análise da frota pesqueira artesanal da comunidade da Raposa, São Luís, MA. Acta Amazonica, 52(2): 247-259.

FABRÉ, N. N. \& BATISTA, V. S., 1996, Determination of the fishing effort unit of serreira drift gill net fishery, Maranhão, Brazil. Ciên. Cult., 48(4): 256-261.

FONTELES-FILHO, A. A., 1968, Sobre a captura e abundância da cavala e da serra nos pesqueiros do Estado do Ceará. Arq. Est. Biol. Mar., Univ. Ceará, Fortaleza, 8(2): 133-137.

FONTELES-FILHO, A. A., 1988, Sinopse de informações sobre a cavala, Scomberomorus cavalla (Cuvier) e a serra, Scomberomorus brasiliensis Collette, Russo and ZavalaCamin (Pisces, Scombridae), no Estado do Ceará, Brasil. Arq. Ciên. Mar., 27: 21-48.

GESTEIRA, T. C. V., 1972, Sobre a reprodução e fecundidade da serra, Scomberomorus maculatus (Mitchill), no Estado do Ceará (Brasil). Arq. Ciên. Mar., 16(2): 83-86.

GESTEIRA, T. C. V. \& MESQUITA, A. L. L., 1976, Época de reprodução, tamanho e idade de primeira desova da cavala e da serra na costa do Estado do Ceará (Brasil). Arq. Ciên. Mar., 16(2): 83-86.

GORBUNOVA, N. N. \& SALABARRIA, D., 1968, Reproduction of scombroid fishes (Pisces, Scombroidei) in western regions of the Atlantic Ocean. Inter-Am. Trop. Tuna Comm., La Jolla, 24p.
GRIFFITHS, R. C. \& SIMPSON, J. G., 1972, An evaluation of the present levels of exploitation of the fishery resources of Venezuela. Fisheries research and development project, MAC-PNUD-FAO. Ministerio de Agricultura y Cria de Venezuela, Serie Recursos y Exploración Pesqueros, Caracas, Venezuela, 2(5): 52p.

MENEZES, M. F., 1970, Alimentação da serra, Scomberomorus maculatus (Mitchill), em águas costeiras do Estado do Ceará. Arq. Ciên. Mar., 10(2): 171-176.

MENEZES, M. F., 1976, Aspectos biológicos da serra Scomberomorus maculatus (Mitchill), capturada por currais de pesca. Arq. Ciên. Mar., 16(1): 45-48.

MOYLE, P. B. \& CECH JR., J. J., 1982, Fishes: an introduction to ichthyology. Publ. Prentice-Hall, INC, 593p.

ODA, 1988, Review of the artisanal fishery in Maranhão State, Brazil. ODA Publ., London, 131p.

STEEL, R. G. D. \& TORRIE, J. H., 1985, Bioestadística: Principios y procedimientos. Ed. McGraw-Hill, Bogotá, $621 \mathrm{p}$.

STEVENSON, D. K., 1981, A review of the marine resources of the Western Central Atlantic Fisheries Commission (WECAFC) region. FAO Fish. Tech. Pap., 211: 133.

STURM, M. G. de L., 1978, Aspects of the biology of Scomberomorus maculatus (Mitchill) in Trinidad. J. Fish. Biol., 13: 155-172.

SUDAM, 1983, Caracterização ambiental e prospecção pesqueira do estuário do Rio Cururuca, Maranhão. SUDAM Publ., Belém, Brazil, 141p.

SUDAM/UFMa, 1985, Prospecção pesqueira do estuário do Rio Paciência, Maranhão. Parte II - Crustáceos e peixes. Relatório final. UFMa Publ., São Luís, Brazil, 57p.

SUDENE, 1976, Pesquisa dos recursos pesqueiros da plataforma continental maranhense. SUDENE, Estudos de Pesca, Brasília, Brazil, 6, 67p.

SUDEPE, 1976, Prospecção dos recursos pesqueiros das reentrâncias maranhenses. SUDEPE, Brasília, Brazil, $120 \mathrm{p}$. 